\title{
LEGALITET, EFFEKTIVITET OCH LEGITIMITET SOM KRITERIER FÖR STRAFFRÄTTENS NORMATIVA KOHERENS
}

\section{Av KJELl SEvóN}

\section{BEGREPP OCH PRINCIPER}

De allmänna lärorna inom ett givet rättsområde kan enligt min uppfattning studeras utgående från två funktionella aspekter. Dessa funktioner eller uppgifter tolkar jag:

a) å ena sidan som lokaliserandet och definierandet av det för handen varande juridiska problemet. Detta kan man se som en förutsättning för att man skall känna igen det rättsligt relevanta i en a priori indifferent händelse, alternativt ett tillstånd. För att vara exakt borde man egentligen tala om att konstruera eller bestämma det rättsligt relevanta. ${ }^{1}$

b) å andra sidan uppfattar jag de allmänna lärornas funktion som systematiseringen av ett givet normmaterial i avsikt att få till stånd någon grad av normativ koherens. Detta kan ses som en förutsättning för att tala om ett rättsystem i motsatts till en rättsordning. Skillnaden mellan ett rättssystem och en rättsordning förstår jag som skillnaden mellan en uppsättning normer och skapandet av en systematik inom detta normmaterial (se t.ex. Björne 1986 och Pöyhönen 1989).

Vi kan försöka precisera förhållandet mellan »lokaliseringen« av det rättsligt relevanta och den normativa koherensen i de allmänna lärorna med hjälp av ett historiskt exempel: Man kunde säga att upplysningens naturrättsliga doktriner såg lösningen på båda uppgifterna huvudsakligen i vissa grundläggande utomrättsliga principer vilka skulle styra den rationella rätten, medan begreppsjurisprudensen försökte lösa båda uppgifterna framförallt genom ett som adekvat betraktat begreppssystem. Vardera utgångspunkten har som bekant i huvudsak förkastats inom modern rättsteori.

Skiljer vi mellan de grundläggande begreppen och de allmänna principerna i de allmänna lärorna inom ett rättsområde kan vi i anslutning till Kaarlo Tuori se deras inbördes förhållande på följande sätt: De grundläggande begreppens funktion är att lokalisera och definiera det juridiska problemet, medan de allmänna principerna tjänar som hjälpmedel i skapandet av ett normativt koherent system (Tuori 1990, 54-59, 1987).

Inom straffrättens område kan t.ex. legalitetsprincipen, proportionalitetsprincipen, preventionsprinciperna samt konformitets- och skuldprincipen betraktas som sådana allmänna principer. Begreppen rättsgoda, handling och (begreppet) skuld 
kan igen betraktas som grundläggande straffrättsliga begrepp. I ett annat rätts- eller tankesystem kunde »rättsgoda« kanske ersättas t.ex. med den individuella rättighetens eller samhällsförsvarets begrepp, begreppet handling ersättas med begreppet personlighet eller konflikt, begreppet skuld med begreppen samhällsfarlighet eller avvikande o.s.v.

Trots att jag tenderar att betrakta de grundläggande begreppen som logisk primära i förhållandet till de allmänna principerna - åtminstone i en temporal eller kronologisk mening - är utgångspunkten för denna framställning frågan om koherens.

\section{NORMATIV KOHERENS}

Koherens hänvisar till en avsaknad av intern motstridighet. När vi talar om normativ koherens är det dock fråga om något annat eller något mera än enbart logisk konsekvens. Termen koherens kunde preciseras i förhållande till kravet på konsistens. När frågan om intern systematik ställs t.ex. inom analytisk filosofi är intresset främst inriktat på frågan om formella inomspråkliga förhållanden mellan meningar eller propositioner - eller relationerna mellan matematiska kalkyler (se t.ex. von Wright 1968). I det följande betecknas detta som konsistens.

För rättens del innebär kravet på konsistens bland annat att tolkningen skall ske med hjälp av vissa grammatikaliska och logiska regler (och att lagstiftningen på motsvarande sätt skall vara fri från logiska motsättningar). Men redan när man t.ex. skall avgöra vilken av två prima facie tillämpbara regler som utgör huvudregel och vilken undantag måste man dessutom tillämpa metaregler som till sin karaktär är normativa. Man kan t.ex. hänvisa till en hierarkisk indelning av rättskällorna eller till stadgad praxis. I sådana fall där dessa inte ger ledning (eller då man vill bryta praxis) kan man försöka hänvisa t.ex. till de rättspolitiska målsättningarna som ligger till grund för ifrågavarande reglering eller till de principer som allmänts skall tillämpas på ifrågavarande rättsområde. Även om man försöker tillämpa en juridisk metod konsekvent innehåller dessa hänvisningar alltid mera än en hänvisning till en logisk eller grammatikalisk nödvändighet.

När man diskuterar koherens i samband med ett rättssystem är graden av formell konsistens i de interna relationerna mellan språkliga satser därför inte ett tillräckligt kriterium för värderingen av det konstruerade systemet. Koherensen förutsätter dessutom ett slags normativ kompatibilitet, något slags normativ förenlighet mellan de propositioner som framställs. Som Robert Alexy och Alexander Peczenik (1990) har konstaterat kan olika kriterier för koherensen inom ett rättssystem stå i konflikt med varandra. Därför kan koherens som sådan inte utgöra grunden för värderingen av ett (teoretiskt konstruerat) system.

Den normativa koherensen inom straffrätten är beroende av ett antal utomspråkliga förutsättningar och tolkningar som inte kan reduceras till de normativa texter- 
nas interna logik. Dessa »tillägg till texten«, vilka ingår i de normativa texterna som deras förutsättningar hänför sig till de sätt på vilka rätten i allmänhet - och straffrätten i synnerhet - har justifierats eller rättfärdigats, till hur frågan om rättens och straffrättens legitimitet har besvarats.

Det är i själva verket missvisande att ställa frågan om legitimitet i singularis. Som Sakari Hänninen $(1990,1-2,14)$ har konstaterat kan man ställa legitimitetsfrågan i form av vem, varför eller hur. ${ }^{2}$ Detta innebär att legitimiteten kan diskuteras ur flere synvinklar. Denna framställning tar upp några sätt på vilka man har försökt legitimera straffrätten. Avsikten med framställningen är framförallt att kritikiskt granska några av de utgångspunkter varur man i den nyare finska diskussionen sökt kriterier för ett normativt koherent straffrättsligt system. ${ }^{3}$

\section{PROBLEM I OCH FÖR DEN MODERNA STRAFFRÄTTEN}

Eftersom frågan om koherens gäller den normativa sammanhållningen inom ett rättssystem (eller en del av ett sådant) i motsats till konsistens som ett formellt kriterium, kan koherensen inte studeras helt abstrakt eller formellt. I det följande avsnittet försöker jag därför ta upp några enligt min uppfattning aktuella problem i straffrätten.

Mitt första argument bygger på en påstådd allmän trend inom den så kallade välfärdsstatens lagstiftning: kritiker har pekat på tendensen att »frysa ned« samhälleliga intressekonflikter i juridisk form. Lars D. Eriksson (1990) har kallat detta fenomen omvandlingen av rätten till »förstelnad politik«. Med detta avser han att man inte längre löser politiska motsättningar i den parlamentariska politiska processen, utan istället överflyttar dem på, eller bygger in dem i rätten. Dessa inbyggda motsättningar får sitt uttryck i lagstiftning som så att säga drar i olika riktning. Denna förstelnade politik kan man t.ex. upptäcka i generalklausuler, vaga och öppna begrepp samt andra underdeterminerade juridiska konstruktioner.

I grunden anser jag att Eriksson har rätt och att han funnit ett relevant mål för sin kritik. Detta innebär förstås inte utan vidare att också straffrätten skulle påverkas: Erikssons beskrivning har troligen sitt huvusakliga ursprung i förvaltnings- och civilrätten. Mot tesen att den »förstelnade politiken« även trängt in i straffrätten kunde man t.ex. anföra, att straffrätten handlar om distributionen av ont i form av hotet med och verkställigheten av straff, i motsatts till den distribution av gott och materiella fördelar som sägs vara typisk för »välfärdsstaten«. I och för sig anser jag att man bör hålla denna skillnad i minnet, redan för att undvika en förskönande och förenklande bild av den moderna straffrätten som den nuvarande punkten på en mer eller mindre lineär skala av växande »rationalitet« och »humanitet«.

Å andra sidan är skillnaden endast delvis relevant. Straffrätt är även en fråga om distribution av gott, om också endast i andra hand: när straffrätten ger skydd åt ett rättsgott blir den inblandad i kampen om olika intressens prioritet. På den i detta av- 
seende ännu mycket enkla nivån för potentiellt inbördes motstridiga kriminaliseringar kan man fråga sig om vår nya och kommande finska strafflag de facto i vissa fall skyddar itressen även mot det skydd som $i$ samma lag tilldelas andra intressen? Jag tänker t.ex. på det skydd som erbjuds företags- och industriella hemligheter, vilket trots alla motsatta försäkringar - kan komma att tjäna även som ett skydd mot skyddet av exempelvis miljön.

Om vi fortsätter att granska vårt nykodifieringsprojekt, men så att säga förflyttar oss ett steg vidare på domarens tolkningsstege, kan vi diskutera den av Straffrättskommittén uttryckta ambitionen att ersätta den äldre kasuistiska formen för rekvisitsformulering med en »syntetisk metod «. Jag kommer inte att försöka förneka uppriktigheten eller rationaliteten i de skäl som kommittén anfört för denna övergång. Sådana skäl är t.ex. att de »syntetiserande« rekvisiten ger bättre möjligheten att reagera på de snabba förändringarna i samhället än vad den detaljerade och specifierande metoden för rekvisitsformulering erbjuder.

Oavsett om man accepterar rationaliteten i denna justifikation eller inte kan man ställa frågan om hur man skall garantera att legalitetsprincipens förbud mot obestämda kriminaliseringar följs? Straffrättskommittén har försäkrat att förbudet kommer att respekteras särskildt när det gäller allvarliga brott (Komm. Bet. 1976:72). Ett misstänksamt sinne måste dock följa upp med frågan om vem som står som garant för löftet? Problem kommer enligt min uppfattning att uppstå framförallt ifråga om vissa relativt vida och svårbestämmbara definitioner av skyddets utsträckning och omfattning, d.v.s. när det gäller att bestämma det »rättsgoda« som ligger bakom kriminaliseringen.

Men låt oss ta ännu ett steg vidare, närmare den civilisationskritiska skymningszon där kritiken av det moderna samhällets rationalitet spirar. Denna kritik har i olika former blivit en vardagsrealitet även i Finland - utan att lämna ens jurisprudensens ärevördiga fält helt i fred. En förhållandevis rationell (eller rationaliserande?) version av denna kritik har betonat den nya roll som olika former av risker kommit att spela i det (post)industriella samhället. I sin bok »Risikogesellshaft. Auf dem weg in eine andere Moderne« utvecklar Ulrich Beck (1986) en tes om hur det moderna samhället i själva den process, genom vilken de gamla hot som en nyckfull och ogripbar natur eller ett skoningslöst samhälle ställde mänskligheten inför har övervunnits, har kommit att producera en hel serie nya hot som biprodukter. Jag skall endast nämna två av dessa »för-juridiska« hot, för att sedan föreslå ett inomrättsligt:

a) den industriella tillväxten och de teknologiska framstegen har producerat ett hot mot själva grunden för vår existens i form av förstörelsen av den naturliga miljön. De nya miljöhoten är på sätt och vis t.o.m. svårare att handskas med en de gamla hot som naturen stod för, genom att de är en integrerad del av de mänskligt producerade förutsättningarna för vår existens. Förutom att de ställer oss in- 
för val som är svåra att göra innebär dessa hot enorma svårigheter i fråga om fastställandet av kausala relationer. Vi står de facto inför - eller är redan inne i en kamp över kausala förhållanden. Detta tycks leda till att den gamla drömmen om att samhällsvetenskaperna en dag skulle uppnå samma grad av exakthet som naturvetenskaperna, förbyts i en mardröm där naturvetenskaperna förlorar sin kredibilitet visavi prognoser baserade på deras resultat.

b) den materiella och sociala utvecklingen i de industrialiserade länderna har lett till att man i dessa länder övervunnit hotet om absolut fattigdom och hunger. Men detta har inte inneburit att den gamla ojämnlikheten och de gamla orättvisoorna har försvunnit. Fråga är snarare om en reproduktion av dem på en ny och högre levnadsstandard. Samtidigt har avskaffandet av det gamla klasssamhällets strukturer lett till ett samhälle där bristen på jämlikhet individualiserats: istället för tillhörighet till en gång för alla givna klasser har vi blivit beroende av utbildning och kompetens. Arbetslöshet är t.ex. inte längre ett »privilegium« för de underpriviligierade.

Kort och brutalt sagt: om idealbilden av vårt samhälle utgår från att så gott som vem som helst kan klättra upp för den sociala stegen, innebär dess spegelbild att nästen vem som helst också i princip står inför risken att falla ned för samma stege. Risken av att inte lyckas måste dessutom bäras av dig »fûr dich «, eventuellt med liten bakgrundserfarenhet av vem du är »an sich«. Detta kan även ställa oss inför nya hot med ursprung i bristande samhällelig jämlikhet. Det handlar inte längre om risk för vålsamma konflikter om kollektiva intressen, men om risk att bli offer för till synes oförklarbara och irrationella våldshandlingar, som t.ex. fotbollsvåld och gatuvåld. Fall där offrets identitet i stort sett är utan betydelse.

c) det kanske viktigaste problem som de nya hoten tycks leda till är att de skapar ett kulturellt tillstånd av odefinierad, oförståbar och okontrollerbar fara, vilket i själva verket påminner om den premoderna visionen av en värld full av demoner och krafter som står utom det mänskliga förnuftets räckvidd. Reaktionerna kan även tänkas påminna om de premoderna: symboliska gester som tillgrips utan några garantier för deras effektivitet, men med tron på eller hoppet om att det onda skall vika för symbolernas magik (se Hassemer 1989).

Detta är naturligtvis endast en av de tänkbara bilderna av det moderna samhället. I den mån bilden är relevant berör den dock omedelbart straffrätten. Jag vill än en gång återkomma till vår nya/kommande strafflag. Reforman kommer att innebära en märkbar ökningen av faredelikten i strafflagen. Straffrättskommittén motiverade i tiden tyngdpunkten på faredelikt med att man vill förebygga skadan innan den inträffat. Denna synpunkt är lätt att förstå, och skảlet kan mycket väl även vara sant. Om denna utveckling dock är internationell kan man trots det ställa frågan om i vilken mån trenden även avspeglar en upplevelse av att man på något sätt måste kontrollera de växande riskerna i det moderna samhället. 
Felix Herzog (1989, III) har nyligen beskrivit den straffrättsliga utvecklingen i Förbundsrepubliken Tyskland med att konstatera att om man är exakt, kan man inte längre tala enbart om prevention av fara, utan om prevention av en hypotes om fara. Detta innebär att man sysslar med mer eller mindre sannolika relationer mellan ett givet handlande och möjliga skador på ett skyddat rättsgott. Detta ställer den straffrättsliga dogmatiken inför svåra problem. När Dan Frände nyligen analyserade rekvisiten för fara i vår hittills senaste uppsättningen av föreslagna kriminaliseringar, hittade han fyra olika sätt på vilka begreppet fara användes. En del av dem föreföll rätt svåra att få grepp om med den precision som man kunde förvänta sig när fråga är om strafflagstiftning (Frände 1990, LaVo 1/89).

Åtminstone en sak förefaller uppenbar: en klassisk bild av förhållandet mellan lagstiftaren och domaren bryts sönder: bilden av domaren som »subsumerar« händelser eller tillstånd, tagna ur verkligheten, under den av lagstiftaren antagna lagen med hjälp av en deduktiv eller syllogistisk modell, där rättsnormen eller -normerna utgör översats och fakta i målet undersats (Aarnio 1983, Hellner 1988).

Vi vet föstås att rättsteorin för länge sedan har visat att bilden av domaren som en »subsumptionsmaskin« utgör en bristfällig beskrivning av rättstillämpningen. ${ }^{4}$ Kritiken rör sig framförallt på rättstolkningens område - där ståndpunktern för närvarande sträcker sig från uppfattningen att tolkningen är totalt indeterminerad (t.ex. Kennedy 1985) över tilltro till hermeneutik och »rättskulturen« (t.ex. Aarnio 1989) till (ännu) mera traditionella ställningstaganden. Den »gamla« modellen är dock fortfarande en grundläggande referens för legalitetstraditionen. Denna utgör en av grundpelarna i den »moderna« straffrätten, då man med »modern« avser ett på promulgerade kriminaliseringar uppbyggdt system (så t.ex. Jareborg 1985, 2).

Då framställningen gäller straffrättens normativa koherens kunde vi fråga oss huruvida andra krav som kan ställas på straffrättens kunde uppfylla det tomrum som legalitetskravet möjligen lämnat öppet i detta avseende? Ett sådant krav kunde vara kravet på effektivitet.

\section{MATERIELL OCH FORMELL RATIONALITET}

Ett tema i diskussionen om legalitet och effektivitet i rätten har varit påståendet att »rättsstaten « bryts ned av den såkallade »välfärdsstatens « interventionistiska regleringar (t.ex. Habermas 1988a, 332-366; 1988b, 530-547; Tuori 1990 37-42).

Detta är på intet sätt ett nytt tema. Ur sociologisk synvinkel utgör Max Webers anays en klassisk utgångspunkt. Weber utgick från en beskrivning av den »rättsstaliga« eller liberal rätten som formellt rationell:

Han ansåg att rätten var rationell i den meningen att varje tillämpning av denna rätt $\mathrm{i}$ ett enskildt fall bygger på allmänna normer som tillsammans bildar ett logiskt och motsättningslöst system. Metoden för att tillämpa systemet skulle vara logisk tolkning av betydelser eller mening. 
Med formaliteten avsåg Weber för det första att ett avgörande moment i rättsligt beslutsfattande låg $\mathrm{i}$ formerna och procedurerna för rättsliga beslut. För det andra avsåg han de rättsliga normernas självständighet i förhållandet till andra normsystem; moral, religion eller samhälleliga konventioner (se Tuori 1990, 7-9, 12-15).

Enligt Weber hotades denna formella rationalitet av att materiella intressen och krav på social rättvisa trängde in i den juridiska beslutsprocessen som en föjld framförallt av att man vid sekelskiftet började erkänna existenssen av motstridiga klassintressen i samhället. Den »välfärdsstatliga« utvecklingen innebar att såväl samhällspolitik som »materiell rättvisa« kom att påverka de juridiska besluten, vilket enligt Weber var förödande med tanke på rättens formella rationalitet. Weber åskådliggör utvecklingen med exempel även ur straffrätten, varvid han särskildt riktar kritik mot de krav på »materiell rättvisa som lekmannadeltagandet i rättegången enligt honom fört med sig. Han ansåg att detta har en nedbrytande inverkan på den formella rationalitet som upprätthållits av den juridiska professionen (Weber 1980, 503-513).

Vi kunde jämföra grunderna för Webers oro med linjemotsättningarna inom straffrättslig doktrin vid sekelskiftet genom att ta debatten mellan Karl Binding och Franz von Liszt som exempel. Därvid bör vi dock hålla i minnet att det alltid är en aning prekärt att tala om »välfärdsstaten«, med en association till distribution av »det goda« i samband med straffrätt, där man framförallt distribuerar ont. Det torde i själva verket vara bättre befogat att tala om ett komplex av förändringar inom rätt och samhälle än om en övergång från »rättsstat« till »välfärdsstat«, vilka inbegriper såväl fördelningsfrågor som utveckling i maktteknologi. ${ }^{5}$

När Binding anklagade von Liszt för att missförstå frågan om straffets justifikation och mål anser jag att kritiken var berättigad såtillvida, att von Liszts blinda tro på de nya empiriskt orienterade samhällsvetenskaperna t.ex. ledde honom att tro på möjligheten att bestämma det enskilda straffet utgående från en förutsägelse om »brottslingens« framtida beteende. Enligt Binding missade han därmed poängen att straffet följde direkt på lagbrottet: genom att bryta mot en handlingsnorm som ingick som ett positivt krav i den norm som kriminaliseringen uttryckte, hade personen ifråga enligt Binding på sätt och vis förtjänat straffet.

Binding tycktes i sin tur ha liten förståelse för aktiv samhällskonstruktion genom lagstiftning. Om rättssystemet en gång är autonomt i förhållandet till övriga normsystem, varför kunde man då inte försöka realisera vilka målsättningar som helst med hjälp av rättssystemet? (Binding 1907, I-XVIII, von Liszt 1982).

Denna motsägelse träffar dock inte nödvändigtvis Max Webers kritik av rättens "materialisering«: Weber bestred inte att lagstiftningen kunde, och enligt honom borde, vara målrationell. Det han motsatte sig var att den formella rationaliteten på nivån för rättstillämpning bröts. ${ }^{6}$

Ett slags specifiering av rättens rationalitet enligt systemet handlingsnivåer ingår i 
Nils Jareborgs analys av det straffrättsliga systemet, varför jag i följande avsnitt försöker redogöra för hans tankar i detta avseende.

\section{NIVÅINDELNING OCH ARGUMENTATION}

I en artikel om »Straffets syfte och berättigande « ${ }^{7}$ har Jareborg betonat komplexiteten av frågor i diskussionen av straffets ändamål och justifikation. I hans följe kan vi urskilja:

1) skillnaden mellan skäl inom det straffrättsliga systemet och skäl som rör systemet som helhet;

2) skillnaden mellan de olika nivåerna inom systemet (Kriminalisering - dom - exekution); och

3) skillnaden mellan varför-frågor och hur-frågor (Jareborg 1985).

Jareborg hävdar, att nivån för kriminaliseringar måste följa en utilitaristisk rationalitetsmodell: en typ av beteende kriminaliseras emedan man vill förhindra - eller rättare sagt minimera - dess förekomst. Den intensitet med vilken man vill förhindra förekomsten av en typ av beteende borde då avgöra hur allvarliga påföljder lagbrytaren hotas med. På nivån för rättstillämpning borde man inte längre utgå från utilitaristiska hänsyn utan följa en (»förtjänst«)modell, som baserar sig på hur allvarlig den handling som skall bedömas är samt gärningspersonens skuld. På nivån för verkställighet är slutligen den enda nödvändiga grunden existenssen av en dom - vilket inte alltid utesluter avvikanden i mildare riktning.

Denna förenklade bild av Nils Jareborgs tankar kan kanske tjäna som en modell för hur man kan försöka lösa dilemmat mellan »rättsstatlig« och »välfärdsstatlig« straffrätt genom att urskilja skilda logiker på de olika handlingsnivåerna inom det system av institutionaliserade kompetenser som hänvisar till straffrätten. Men samtidigt påvisas även skillnaderna mellan frågan om varför vi gör något (vilken borde besvaras genom att man rättfärdigar själva det mål man eftersträvar) och frågan och hur vi försöker nå vårt mål (vilken borde besvaras genom en justifikation av de medel och metoder som används) samt frågan om vem som skall ges rätt att besluta $i$ de föregående frågorna - eller å andra sidan på vems vägnar beslutet fattas.

Relevansen av dessa distinktioners har dock ifrågasatts inom nyare, framförallt argumentationsteoretiskt inspirerad rättsteori. Jürgen Habermas har t.ex. nyligen avslutat en artikel om förutsättningarna för en sådan rationell argumentation som "genomtränger såväl berättigandet som tillämpandet av normer« med att hävda, att »vi idag måste överge t.o.m. det normativa schemat för den klassiska maktfördelningen « $(1989,154)$. Denna logik framträder enligt min uppfattning i vissa nyare teorier där rättsprincipernas betydelse i rättstillämpningen betonats. Jag vill därför ta upp vissa idéer som framförts av Ronald Dworkin (1981 och 1986) och Robert Alexy (1983 och 1986), emedan de tycks ha haft kännbart inflytande på den nyare finska straffrättsliga diskussionen. ${ }^{8}$ Trots att dessa teorier säkert redan börjar vara 
allmänt kända försöker jag först ge en bild av de drag i dessa teorier som jag anser vara centralast för vårt tema. Därefter försöker jag formulera några kritiska kommentarer som jag hoppas hjälper att specifiera frågan om »effektivitet, legalitet och legitimitet« som kriterier för ett straffrättsligt systems koherens.

\section{MODELLER FÖR PRINCIPAVVÄGNING}

Enligt Dworkin är rättsprinciper en typ av rättsnormer. De skiljer sig från rättsregler framförallt i följande avseende: principerna kan inte tillämpas enligt en »antingen eller « - modell. Till skillnad från tillämpningen av rättsregler, där domaren har att avgöra om en regel kan tillämpas på rättsfakta eller inte, påverkar principerna den riktning i vilken avgörandet bör sökas. Exaktare uttryckt påverkar rättsprinciperna enligt denna tolkning valet av argument och vilken vikt dessa skall ges $\mathrm{i}$ avgörandet.

Dworkins teori betonar individens rättigheter och friheter som grundläggande värden i rättssystemet. Inom normkategorin rättsprinciper skiljer han därför mellan principer i snäv betydelse och s.k. »policies«. De förra är förbundna med med individuella rättigheter och friheter medan de senare representerar statlig styrningsaktivitet med »kollektiva goda« som mål. Dworkin talar om båda principkategoriernas tyngddimension. Med detta avser han att då principer och/eller principer och "policies« kolliderar - han använder termen principkollision i motsatts till regelkonflikt - bör de balanseras och avvägas mot varandra. Då Dworkin betonar den rättvisa fördelningen av individuelle rättigheder och friheter som rättsordningens grundläggande uppgift, föreslår han att rättstillämpningen bör ge principerna $\mathrm{i}$ snäv bemärkelse (åtminstone) en prima facie prioritet i kollisioner med "policies«.

Det är särskilt två aspekter av Dworkins teori jag anser vara öppna för kritik:

För det första förefaller det som om teorin inte skulle kunna svara på de styrningskrav som ställs på den moderna rätten. Dessa krav på en styrningskapacitet, vilka ofta kombineras med »välfärdsstaten«, har - som ovan konstaterats - sitt ursprung ambitionen att aktivt förändra samhället med hjälp av rätten. Om och när detta resulterar i juridiskt »förstelnad politik«, borde orsakerna kanske sökas i en ovilja eller alternativt oförmåga att på den politiskt/parlamentariska nivån lösa den etiska frågan om vilka samhälleliga goda vi önskar befrämja.

För det andra tycks Dworkins modell innebära att domaren (enligt Dworkins superdomare Herkules exempel) i s.k. »hard cases « borde söka avgörandet utgående från vad som skulle vara en rättvis lösning. Detta tyder på en moraliskt färgad rättvisestandard. Detta väcker frågan om var man skalls söka moralen? Skall domarens personliga moral utgöra standarden? Dworkin försöker förneka detta genom att hävda att domaren bör söka svaret i de värden som av nöden ligger som grund för de moderna västerländska rättsordningarna. Han argumenterar att rätten måste vara rättvis för att vara rätt. Den måste enligt honom således vara moraliskt accep- 
tabel i någon mening. Som Roger Cotterell $(1989,174-175)$ har visat för detta Dworkin nära den klassiska Common Law doctrinens föreställning av domaren som »finner« rätten. Därmed stöter han på problemet att förklara hur rätten kan hittas i tidigare, äldre rättsliga avgöranden, en tankegånd som redan John Austin och Jeremy Bentham riktade kritik mot (se Cotterell 1989, 52-82). Man kan även fråga sig varför i äldre avgöranden uttryckta värderingar skulle utgöra ett bindande värdesystem för nulevande personer? Som Ingeborg Maus har konstaterat, innebär utplånandet av skiljelinjen mellan rätt och moral en risk för att medborgarna möjlighet att rikta kritik mot rättsordningen ur moralisk synvinkel försvagas (Maus 1989, se även Eriksson 1990).

Robert Alexys teori påminner om Dworkins framförallt $i$ det avseendet att även Alexy har utvecklat en modell för hur rättsprinciperna skall behandlas i det juridiska beslutsfattandet. Som Dworkin tolkar han rättsprinciperna som en form av rättsnormer. Enligt Alexy kan rättstillämpningen betraktas som en rationell diskurs, ett argumentationsförfarande. Då rättskällorna definierar vilka argument som kan framföras, bestämmer diskursreglerna hur argumenten skall underbyggas och hur deras relevans skall värderas.

Alexy försöker ge formella kriterier för när en princip skall tilldelas större betydelse än en annan i »kollisionslägen «. Sådana formella kriterier har Alexy sammanfattat i en »kollisionslag", vilken bl.a. innebär att man skall beakta den intensitet med vilken en princip berörs i det konkreta fallet. Vidare bör man beakta i hur hög grad en kolliderande princip måste vika för en annan, d.v.s. i vilken mån ett avgörande på basen av argument som understöds av en princip innebär att konkurrerande värden eller målsättningar ignoreras i det konkreta fallet. Alexy betonar dock inte på samma sätt som Dworkin »principernas « företräde framom »policies«.

Alexy kunde därigenom tänkas undvika de problem vi såg hota Dworkins konstruktion: dels balanserandet mellan »eviga«, eller åtminstone immanenta värden i rätten och samhällelig förändring, dels bristande förmåga att förklara varför de principer som hänför sig till individuella rättigheter och friheter skulle vara priviligierade i förhållandet till kollektiva samhälleliga mål. Vid närmare undersökning kan det dock visa sig att Alexy ställer oss inför nya problem istället för dem han löser:

För det första antar Alexy, precis som Dworkin, att det finns en förbindelse mellan rätt och moral. ${ }^{9}$ Även om Alexys uppfattning av moralen som procedural moral skiljer sig från Dworkins, öppnar även han på sätt och vis rättstillämpningen för argument med moralisk natur.

Alexy tycks dock öppna rättstillämpningen även för argument över vad som skall anses rationellt med tanke på vad som är ändamålsenligt. Denna typ av argument kan ha två slags karaktär: man kan antingen jämföra målsättningar med an- 
dre målsättningar, eller diskutera medel i förhållandet till mål. I den senare formen av argumentation blir effektivitetsargument centrala.

Förhållandet mellan de två formerna för ändamålsenlighetsargumentation kan även vara sådant, att valet av mål kan vara ett effektivitetsargument $\mathrm{i}$ en diskussion av etisk eller politisk natur: man kan argumentera att valet av en viss målsättning utgör det effektivaste sättet att befordra ett mål av mer allmän karaktär, t.ex. »samhällets bästa«. När denna typ av argumentation accepteras i rättstillämpningen, innebär det att domaren måste överväga följderna av sitt avgörande och ställa olika förväntade konsekvenser i inbördes rangordning.

Särskilt när det gäller beaktandet av effektivitetsargument leder denna aspekt av Alexys modell enligt min uppfattnig till större problem ifråga om straffrätten än t.ex. ifråga om civil eller förvaltningsrätt. ${ }^{10}$

\section{EFFEKTIVITET OCH LEGALITET}

Man kan, som Liisa Uusitalo $(1989,198)$ ifrågasätta det berättigade i en helt ineffektiv rättslig reglering. Då vi diskuterar de krav på effektivitet som ställs på straffrätten talar vi idag framförallt om straffrätten som medel för samhällelig styrning, vilken förväntas uppnås genom preventiva effekter. Denna styrningseffekt kan vi dels granska som styrningens effektivitet $i$ allmänhet, dels som frågan om vilka och vems intressen tillämpningen skall vara inriktad på att effektivt skydda.

När det gäller styrningen i allmänhet kunde man hänvisa till Winfried Hassemers (1989) tes att antalet sådana ineffektiva (»symboliska«) kriminaliseringar ökar, sokm antagits huvudsakligen som en ursäkt för att man inte finner eller utnyttjar effektiva medel för att lösa existerande problem - t.ex. i fråga om miljöförstöringen. Men även effektiviteten i bekämpningen av - åtminstone brottsbeskrivningsenligt sett - »traditionellare risker « med straffrättens medel kan försvagas till den del den »irrationella« eller »meningslösa brottsligheten« ökar.

Detta problem gäller framförallt lagstiftaren. Man dock göra följande invändning mot Hassemers kritik: kriminaliseringens direkt målrationella, i princip med effektivitetskriterier mätbara funktion behöver inte nödvändigtvis sammanfalla med kriminaliseringens symbolfunktion. Symbolfunktionen kan även tolkas som en form av samhällets interna kommunikation, varvid effektivitetskriteriet inte kan utgöra en likadan måttstock som vid bedömningen av »direkt prevention«. Detta innebär dock att det ifråga om »symboliska kriminaliseringar« (den symboliska aspekten av kriminalisering) är svårt att motivera beaktandet av effektivitetshänsyn på nivån för rättstillämpning.

Vad gäller frågan om vilka eller vems intressen som domaren effektivt skall befrämja, eller frågan om hur effektivt de bör befrämjas, behöver man uppenbarligen någon annan måttstock än effektiviteten i sig. Effektivitetsargumentet lämpar sig 
bättre då det gäller att avgöra vilka medel som bör användas, än då fråga är om att rättfärdiga målen (von Wright 1989, 123).

Om effektiviteten är ett argument bland andra i en »principavvägning« eller »argumentationsmodell « av typ Dworkins och Alexys modeller för rättstillämpningen förefaller det som om rättstillämpningen därmed öppnas för beaktandet av enskilda och partikulära intressen. Det kan, som Ingeborg Maus (1989, 153-154) har visat, leda till att rättstillämpningen öppnas för administrativa hänsyn. Inom ramen för det straffrättsliga systemet är detta inte särskilt önskvärt; de exeptionella befogenheter systemet ger representanterna för statsmakten bör enligt min uppfattning så entydigt som möjligt avgränsas i riktning mot administrationen. Min uppfattning är därför den, att argumentation som stöder sig på effektivitetshänsyn närmas kan ha en begränsande funktion i justifieringen av straffrätten, däremot inte underbygga en positiv legitimation.

Det förefaller även att en modell för principavvägning, som beaktar effektivitetshänsyn, kunde komma i konflikt med den straffrättsliga legalitetsprincipen, då avvägningen sker på nivån för rättstillämpning. I detta avseende kan man tänka sig att Dworkins modell med betoning av individuella fri- och rättigheder eventuellt skulle vara bättre försvarbar. Man kan t.o.m. tänka sig, att denna modell skulle innehålla element av en positiv justifikation av riktlinjerna för avgörandet. Emedan vardera modellen utgår från att rättsliga avgöranden bör kunna underbyggas med argument som rättfärdigar dem, är det skäl att granska sätten att underbygga legalitetsprincipen innan vi försöker svara på dessa frågor.

Legalitetsprincipen ställer krav på avgörandets förutsägbarhet. Kravet på förutsägbarhet har i sin tur ofta baserats på medborgarnas förväntningar på rättssäkerhet (t.ex. Aarnio 1989 18-19). Försöker vi specifiera varför detta krav borde respekteras kan vi skilja mellan en sociologisk eller empirisk utgångspunkt och en normativ utgångspunkt:

Utgår vi, som t.ex. Tapio Lappi-Seppälä gör, från den empiriska synvinkeln blir det kanske slutligen en fråga om samhällelig stabilitet: det moderna samhällets komplexitet kräver förutsägbarhet, medborgarna skulle förlora sin tilltro till rättssystemet i fall förutsägbarhetskravet inte uppfylls i tillräcklig grad. " Dessa förväntningar behöver inte nödvändigtvis enbart vara av »formell« natur, utan kan även utgöra förväntningar på en förutsägbar »policy« eller ett »materiellt« sett rättvist avgörande. Följer man denna tolkning förefaller det möjligt att förutsägbarheten i kombination med ändamålsenlighetskriterier skulle kunna bilda grunden för ett normativt koherent straffrättsligt system.

Utgår vi från den normativa synvinkeln kan förväntningen på förutsägbarhet grundas på säkrandet av den frihetssfär som respekten för den individuella autonomin kräver. Den individuella autonomin kan då, som Dan Frände gör, betraktas som ett grundläggande krav som den »mänskliga integriteten« eller »människovär- 
det« ställer på rätten och dess tillämpning. Då »förväntningarnas« justifikation tolkas i denna riktning kommer man att betona den »formella" riktigheten i avgörandet snarare än den »materiella«. Denna tolkning tycks tyda på att förutsägbarheten skulle innehålla en självständig grund för straffrättens normativa koherens. ${ }^{12}$

Utgår vi från »berättigade förväntningar « på acceptabla policies eller »materiell« rättvisa, tycks Alexy komma närmare idealet, dock med en eventuell förlust inom området för sådan individuell autonomi, som man alltid kunde kräva en justifikation för. Utgår vi från »autonomin « kunde Dworkin komma närmare idealet, dock med den tidigare nämnda risken för en förlust i rättens styrningskapacitet, varför även denna lösning borde kunna justifieras konkret.

Frågan om vilken utgångspunkt som är att föredra kan enligt min uppfattning inte som sådan lösas med absoluta eller a priori kriterier. Å ena sidan kan man säga att även »berättigade förväntningar « på »materiellt sett « riktiga eller ändamålsenliga lösningar måste formaliseras på något sätt, om man vill försäkra sig mot ett partiskt uppfyllande av enskilda förväntningar in casu. Å andra sidan kan man, som Kaarlo Tuori (1988b, 200-201) har konstaterat, även kräva en innehållsmässig - och i denna mening materiell - justifikation av den »formell rättvisan«, varför den s.a.s. står på samma startlinje med andra tolkningar av rättvisa.

Min slutsats blir, att de anförda argumentationsmodellerna inte förmår erbjuda genvägar till ett »koherent system «, förbi frågan om urskiljandet av handlingsnivåer inom systemet. En genväg kräver att rättstillämpningen s.a.s. direkt kunde rättfärdigas. Effektivitetsargumentationen tycks dock närmast kunna erbjuda negativa begränsningar för, inte ett positivt berättigande av, det straffrättsliga systemet. Legalitetskravet tycks för sin del ha en status av förutsättning för, inte justifiering av, den straffrättsliga praxisens legitimitet.

Samtidigt innebär dessa "principmodeller « (såväl Dworkins som Alexys) en förskjutning av makt från lagstiftaren till domaren (se Maus 1989 och Eriksson 1990). Om vi utgår ifrån att behovet att grunda straffrättens legitimitet aktualiseras uttryckligen av den med (straff)rätten förbundna maktaspekten, kan vi ställ frågan om hur detta maktskifte påverkar straffrättens legitimitet? Svaret påverkas enligt min uppfattning av hur legitimiteten tolkas. Vi kan igen skilja mellan en empirisk och normativ utgångspunkt: mellan faktisk acceptans och acceptabilitet (se t.ex. Habermas 1976 och Tuori 1988a).

\section{EMPIRISK OCH NORMATIV LEGITIMERING}

Utgår man från den faktiska acceptansen av rätten innebär detta att man hävdar, att det är tillräckligt om medborgarna accepterar faktiskt förekommande rättsliga avgöranden. Denna utgångspunkt är enligt min uppfattning förenad framförallt med följande problem: utgår man för det första från att »föremålen för, eller par- 
terna i ett rättsligt avgörande skall acceptera detta får man svårligen ett enhälligt bifall; det är förmodligen sällan den förlorande parten i en civilprocess eller t.ex. den till straff dömda i en brottmålsprocess uttrycker sin acceptans av avgörandet. Denna svårighet kan man försöka lösa genom att hänvisa till »det allmänna rättsmedvetandet«. Rättspraxis skall således stå i samklang med ett empiriskt rättsmedvetande.

Det förefaller dock av två empriska skäl svårt att förlita sig på det (empiriskt tolkade) allmänna rättsmedvetandet: å ena sidan tycks det omöjligt för domaren/tillämparen att nå sådan kunskap om medborgarnas rättsuppfattningar som kunde styra avgörandet $\mathrm{i}$ ett konkret fall - $\mathrm{i}$ värsta fall påverkas eventuellt domaren av mediastormar baserade på exeptionella och exeptionellt rapporterade händelser. Å andra sidan är rättsmedvetandet inte enhetligt, utom möjligen i frågor som inte annars heller leder till svårigheter för rättstillämparen. Dessa både drag styrks även av empiriska undersökningar av rättsmedvetandet (t.ex. Blom 1976 och Bondeson 1980).

Dessa svårigheter kan man å sin sida försöka lösa genom att hänvisa till systemacceptans. Därvid utgår man från att det är tillräckligt om åtminstone en tillräcklig del av medborgarna i genomsnitt accepterar rättsystemet i sin helhet. Acceptansen kan antingen gälla systemets »produkter « (avgöranden, resultat) eller allmänna organisations- och funktionsprinciper.

I det första av dessa alternativ gäller problemen dels medborgarnas kunskap om faktisk praxis, såväl dess premisser som slutsatser, dels var gränsen skall dras? Skall rätten t.ex. vara ett ständigt »samspel« med »medborgarolydnad«? Man kan enligt min uppfattning på goda grunder ifrågasätta denna model för rättens legitimering, även om man accepterar medborgarolydnaden som ett sätt att fästa kritisk uppmärksamhet på brister i rätten. Gäller acceptansen det andra alternativet dvs. systemets allmänna organisations- och funktionssätt, kan man ställa frågan hurudan kännedom om systemets funktion detta förutsätter? Är det t.ex. tillräckligt, att en majoritet av medborgarna tror att systemet fungerar på ett visst sätt och enligt bestämda organisatoriska principer, även om detta t.ex. vore en följd av manipulerad publicitet, eller bör det även faktiskt fungera så?

Även då man utgår från acceptabiliteten som kriterium för rättens legitimitet står flera alternativ till buds. En traditionell form av legitimitet utgörs av religiösa världsbilder. Sedan dessa hade förlorat i styrka, d.v.s. erhållit minskad legitimationspotential inom den europeiska rätts- och samhällstraditionen (se t.ex. Habermas 1987), gjordes flere försök att grunda rättens legitimitet inom ramen för den europeiska upplysningen och den moderna s.k. rationella naturrätten (se t.ex. Lagerspetz 1989). Jag vill ta upp ett av dessa försök, vilket kunde kallas modellen för rättens demokratiska legitimering. 


\section{PARTICIPATION OCH ARGUMENTATION}

I upplysningens tradition kunde vi förena tanken på demokratisk legitimation genom participation med Jean-Jacques Rousseaus och Immanuel Kants namn. Den centrala frågan för Rousseau - åtminstone i hans praktiskt-politiskt orienterade arbete om »samhällskontraktet « - var hur en sådan »allmänvilja« kunde uppnås som kunde ge anspråk på att legitimt utfärda bindande normer. Rousseau försökte besvara frågan dels genom att kräva, att makten att ge bindande normer $i$ sig själv inte fick bindas vid givna privilegier d.v.s. fråntas folket, dels genom att kräva att de frågor som reglerades med bindande normer skulle ställa så få restriktioner som möjligt på medborgarnas frihet, varför de skulle svara mot allmänna, för alla gemensamma intressen (Rousseau 1988, 42-62). Dessa frågeställningar övertog även Kant i sin rättsteori.

Kant skiljde som bekant kategoriskt åt rätt och moral som tillhöriga olika begreppsvärldar. I hans tolkning av moralen var kravet på universalisering av maximerna för handling centralt. Detta gällde dock inte som sådant i rättens reella värld: grundkriteriet för rättens »acceptabilitet « var enligt Kant att rätten i form av normer utformats under medverkan av eller möjlighet till medverkan av dem för vilka dessa normer skulle komma att gälla, eller att dessa åtminstone skulle ha accepterat dem ifall de haft denna möjlighet (Kant 1986, 27-49, 127-154). ${ }^{13}$

Rättstillämpningen behövde därför inte, och skulle inte heller i motsats till det universaliseringskrav ifråga om de handlingsmaximer som hörde till moralens område grundas på en test av de normer som tillämpades. Kant såg rättstillämpningen enligt den »subsumptionslogiska « modellen, där lagstiftningen utgjorde den översats under vilken en handlingsbeskrivning skulle ställas. Det enda egentliga krav som Kant ställde på rättstillämpningen var att denna skulle vara opartisk. Detta innebar, att rättstillämpningen fick sin legitimitet direkt och endast via lagstiftningens legitimitet.

Det är i grunden denna »kantianska modell« för rättens legitimitet som har inskrivits i de s.k. västerländska demokratiernas konstitutionella garantier för fri viljebildning, medborgar- och demokratiska rättigheter och myndigheternas lagbundenhet. Det faktiska förverkligandet av denna modell har dock varit problematiskt. Själva grundrelationen mellan politik och rätt har utgjort ett problem inom »rättsstatstraditionen « - å ena sidan politiken som bas för rätten och å andra sidan rätten som gräns för politiken (se t.ex. Kelsen 1986 och kritiken i Cotterell 1989, 83-117). Den traditionella liberalistiska rättsstaten har samtidigt kritiserats för att den inte garanterade de materiella och kulturella förutsättningarna för jämlikt deltagande i den demokratiska processen (Tuori 1990).

»Välfärdsstaten « har igen sagts komma i konflikt med demokrati genom introduceringen av korporativa styrelsesätt som tränger undan den demokratiska processen till förmån för strategiska kompromisser mellan inflytelserika intressegrupper. Man har även hävdat att olika expertgruppers teknokratiska inflytande leder till ett in- 
strumentellt beslutsfattande, där besluten fattas utgående från - eller åtminstone presenteras som resultat av - systeminterna ekonomiska eller liknande »nödvändigheter (se Tuori 1988a, 1989, 1990). ${ }^{14}$

Framförallt de sist nämda, med välfärdsstaten förbundna avvikelserna från den demokratiska (i webersk mening) »idealmodellen « har varit Jürgen Habermas utgångspunkt $i$ ett flertal arbeten (f.o.m. Habermas 1962). Enligt Habermas vision av en »kommunikativ rationialitet « kan den moderna rätten endas åtnjuta en procedural legitimitet, dvs. endast härledas ur den procedur, det förfarande i vilket rätten antags och tillämpas.

Avgörande för förfarandets legitimitet är tryggandet av deltagarförutsättningarna i beslutsprocessen. Som kritisk måttstock för dessa uppställer Habermas den s.k. diskursetiken. Diskuretikens regler skall garantera rätten för berörda att deltaga i beslutet, att åtnjuta lika respekt för sina synpunkter etc. De krav som ställs på deltagarna gäller framförallt uppriktighet och strävan till »rationell konsensus«. Att man faktiskt uppnår konsensus är dock inte ett kriterium för värderingen av argumentationsförfarandets legitimitet. Innehållsmässigt kan argumenten inte begränsas eller värderas på förhand, utanför den diskursiva processen.

Habermas tenderar, sedan han övergått till ett språkfilosofiskt paradigm, att betrakta sina kriterier som ett slags transcendentala kriterier för samhälleliga beslut, på sätt och vis oberoende av deras institutionalisering. ${ }^{15}$ I detta ingår enligt min uppfattning såtillvida en positiv, kritisk aspekt, att Habermas vägrar binda sitt schema vid existerande former för institutionnalisering som de enda tänkbara. Samtidigt kan man hävda att den »kommunikativa rationaliteten« och »diskursetiken« inte kan ses som överhistoriska kriterier för rättens legitimitet, utan som bundna till ett historiskt samhälle och en historisk rättsform. Man kan ifrågasätta att ett uppfyllande av det formella kravet på ett diskursivt förfarande i verkligheten kan lösgöras från empiriska förhandsuppfattningar om vilken typ av argument som kan framställas i diskursen, d.v.s. från uppfattningar av vad som överhuvudtaget kunde vara föremål för en rationell konsensus.

Därför bör vi enligt min uppfattning, även om vi accepterar ett diskursivt förfarande som en nödvändig förutsättning för rättens legitimitet, ta ett steg mot en empiriskt ställd fråga om faktisk konsensusduglighet. Detta leder till frågan om hur diskursen skall institutionaliseras, d.v.s. på vilket forum och med vilken deltagarkrets diskursen förs. Ifråga om institutionaliseringen blir problemet framförallt $a d$ vokatoriska, eller ställföreträdande diskurser samt simulerade diskurser, där deltagarståndpunkterna föreställs (se Tuori 1988a, 82-87, 157-159; 1990, 252-265).

Ur en empirisk synvinkel har man frågat i vilken utsträckning man kan tala om juridiska »allmänintressen « $i$ ett differentierat och stratifierat samhälle där dessutom olika livssätt, folkgrupper mm. i allt högre grad lever jämnsides? Enligt t.ex. Ingeborg Maus $(1986,319-321)$ förefaller det som om de i egentlig mening konsensdugli- 
ga frågorna skulle utgöra endast en ringa del av den moderna rättens regleringsområde. Detta har väckt krav på en förstärkning av den faktiska participationsmöjligheten i den juridiska diskursen;

När vi talar om ett beslut som fattas på lagstiftningsnivån kan vi betrakta det representativa lagstiftningsförfarandet, där deltagarmöjligheten är delegerad s.a.s. »uppåt«, som ett institutionellt problem. Trots denna »delegering« blir vi oftast tvungna att acceptera någon form av »rättvisa« kompromisser (»fair compromises«) istället för »allmän konsensus« som föremål för och målsättning med besluten. För att stärka den institutionella basen för rättens legitimitet har man därför, särskilt då fråga är om reglering med regional eller personell begränsning och positivia prestationer från statens sida, föreslagit en »delegering nedåt«, kompetens för de direkt berörda grupperna att anta normer på regleringsområdet eller, vilket $\mathrm{i}$ praktiken inte behöver skilja sig så mycket från antagandet, att tolka normerna inom löst satta ramar (t.ex. Tuori 1990, 260, med hänvisning till Maus 1986, 322$323)$.

På grund av det accentuerade tvångsmomentet är normsättningen inom det straffrättsliga systemet i särskilt starkt behov av legitimering. Inom ramen för ett system som bygger på allmänprevention och (i princip) mot alla riktade hot om negativa sanktioner i form av straff, förefaller delegeringsmodellen »nedåt« inte särskildt lämplig för straffrättens del, kriminaliseringsbesluten har på grund av sin allmänna karaktär förbehållits lagstiftaren. ${ }^{16}$

Straffrättskommittén (1976: 72, 12-28) utgick i sitt principbetänkande från att granska området för kriminaliserat betende mot bakgrunden av »samhällspolitikens allmänna målsättningar« som skulle specifieras enligt »centrala livsområden« med hjälp av »sakkunniga« och beaktandet av »olika gruppers« behov av skydd. Även om kommittén - i linje med alla straffrättseperters »ultima ratio«-retorik - betonar att det straffrättsliga hotet skall vara subsidiärt, tycks detta synsätt innehålla möjligheter till den typ av »strategiska kompromisser « och »instrumentellt beslutsfattande " genom vilka man ansett att den participatoriska demokratin bryts ned $\mathrm{i}$ »välfärdsstaten «. Enligt min uppfattning har strafflagsprojektets arbete hittills gett underlag för en såda tolkning (se LaVo $5 / 84 ; 1 / 89$ ). ${ }^{17}$

Då kunde man tänka sig att stärkandet av den straffrättsliga normsättningens legitimitet enligt den »diskursiva modellen« borde innebära att försöka inskränka kriminaliseringarna till »konsensusdugliga« frågor. Detta för tanken närmast till skydd av elementära livsförutsättningar. Detta borde innebära ett verkligt försök att inskränka kriminaliseringarna till ett minimum. Däremot behöver det inte nödvändigtvis tolkas som ett krav på återgång till den liberala »rättsstaten«: man kunde med fog säga att denna (som idealmodell) samtidigt gav ekonomiska privilegier ett överdrivet skydd som förnekade delar av befolkningen elementärt skydd. Det minsta man utgående från en »diskursiv« eller »kommunikativ« legitimitetsmodell kan 
kräva är naturligtvis att det som eftersträvas med kriminaliseringsbeslutet är tillräckligt "gripbart« för att kunna diskuteras och explikerat för att kritik av beslutet skall vara möjligt.

\section{ALLMÄNNA NORMER OCH ENSKILD TILLÄMPNING}

När vi talar om tillämpningen av straffrätten talar vi om ett konkret avgörande $i$ ett enskilt fall, varför man kunde tänka sig att det skulle vara lättare att uppnå, om inte konsensus så åtminstone en »rättvis kompromiss«. Men då vi talar om ett beslut som inte bara fattas i parternas ställe, men utan att åtminstone endera partens vilja ens i princip behöver beaktas, förefaller en »rättvis kompromiss « mellan olika effektivitets- eller rättvisehänsyn inom ramen för den typ av simulerad diskurs som kan föras inför domstol ännu svårare att legitimer än på lagstiftningsnivån.

Det har under senare år framförts ett mångfald av förslag till alternativa former för konfliktlösning som substitut för eller tillskott till straffrätten och -processen. Dessa har haft varierande målsättningar, från konsensusorienterat betraktande av »konflikter som lärdomsprocesser « (i anslutning till Christie 1977) till sådana som är orienterade mot civilrätten genom offerersättning och intressekompromisser (se t.ex. Eser-Kaiser-Madlener 1990). Ett gemensamt drag i dessa förslag är att de söker direkt legitimitet för lösningen genom att förstärka parternas position - dock med mycket varierande orientering. I förhållandet till det »traditionella systemet« förefaller det som om de »konsensusorienterade« förslagen äventuellt kunde uppfylla kravet å »opartiskhet«. Då de framställs som alternativ till (straff)rätten kan de dock inte kombineras med ett ellmänt hot med negativa sanktioner.

De »kompromissorienterade« kunde kanske förenas med ett allmän hot med negativa sanktioner, däremot kunde tillämpningens opartiskhet eventuellt äventyras. Jag skall inte gå närmare in på dena typ av förslag till legitimering, utan hålla diskussionen inom ramen för ett system som bygger på av lagstitaren antagna allmänna straffbestämmelser och diskutera frågan om hur en diskursiv utgångspunkt kunde ge stöd för ett opartiskt tillämpande av dessa.

Klaus Günther (1989) har försökt påvisa skillnaden mellan att rättfärdiga en allmän norm och att rättfärdiga tillämpningen av en norm på ett särskilt fall.

I det första fallet bör man beakta alla tänkbara situationer i vilken normen kunde komma att tillämpas. Utgående från detta bör diskussionen gälla alla tänkbara normer som kunde gälla för alla tänkbara fall inom det område man avser att reglera. Därför kan, och bör man framföra argument som gäller den riktning i vilken man vill påverka samhället, de målsättningar man anser att regleringen bör förverkliga och de förhållanden man anser vara rättvisast mellan människor etc.

När man tillämpar en norm gäller frågan däremot inte vilka målsättningar man villk förverkliga med tillämpningen, vilken tillämpning som skulle befrämja det allmänna bästa eller rättvisa förhållande människor emellan etc. Istället bör man 
framföra argument som stöder tillämpningen av en av eventuellt flere tillbudsstående, prima facie konkurrerande normer (eller alternativt att ingen norm står att tillämpa på en definierad helhet av givna omständigheter). Då man i justifieringen av en norm var skyldig att beakta alla tänkbara tillstånd som normen kunde komma att tillämpas på, är man i tillämpningsdiskursen skyldig att beakta alla sidor och omständigheter som har relevans i det för handen varande fallet.

Mot bakgrunden av denna modell kan vi försöka se vad kraven på legalitet, effektivitet och legalitet kunde innebära för straffrättens koherens då synvinkeln är domarens.

Den demokratiska legitimationen av en satt straffrättsnorm måste på domsnivån komplementeras med konformitetsprincipen: det räcker inte att normerna har givits i en demokratisk (diskursiv) process, man måste även försäkra sig om att den åtalade faktiskt hade möjlighet att följa normen i det specifika fallet. Följer vi Günthers schema innebär den bedömningen att vi är tvungna att beakta samtliga aspekter av handlingen under de förhandenvarande omständigheterna. I linje med Ari-Matti Nuutila (1990) utgår jag från att beaktandet av alla aspekter av fallet kräver beaktande av såväl vilje- och emotionella-som kognitiva aspekter av handlingen.

I princip innebär detta att jag anser att möjligheten att handla annorlunda - gärningspersonens skuld - inte kan fastställas ur en objektiv synvinkel i den meningen att vi lösgör fastställandet av skulden från den åtalades synvinkel. Denna utgångspunkt pekar i viss mening i en motsatt riktning än utvecklingen inom senare finsk doktrin och praxis, t.ex. trenden att ta »sannolikhetsuppsåt« som gränsdragningskriterium mot vållande.

Det jag eftersträvar bör dock inte förväxlas med en återgång i riktning mot den äldre (finska) doktrinära position som t.ex. Brynolf Honkasalo företrädde, där »den rätta straffrättsliga bedömningen av en gärning « antogs förutsätta beaktandet av det »sinneslag ur vilket gärningen har framsprungit«. Denna konstruktion knöt skulden till gärningspersonens »associalitet«, även om de »associala karaktärsdragen « enligt positiv rätt skulle beaktas endast till den grad det var nödvändigt för att »förstå den enskilda handlingen och dess allsidiga straffrättsliga bedömning « Honkasalo 1967, 18). »Allsidigheten « $\mathrm{i}$ en dylik bedömning innebär inte (ens) ett försök till »simulerad diskurs«, utan att domstolen (heteronomt) ensidigt konstruerar ett subjekt vars motiv och intentioner tolkas mot bakgrunden av en postulerad »socialitet«.

I förhållandet till denna typ av konstruktioner innebär t.ex. $P$. $O$. Träskmans $(1985,64-73)$ kritik av »viljeteorin « som kriterium för gränsdragningen mellan uppsåt och vållande inte bara »ett steg mot realism «, utan den kan tolkas som ett steg $\mathrm{i}$ riktning mot att försöka beakta åtminstone den handlandes reella kognitiva position. Argumentet mot ett beaktande av volitiva och emotiva aspekter av handlingen (den åtalades motiv och tolkningar) emedan detta skulle leda till oöverstigliga svå- 
righeter ifråga om bevisningen p.g.a. att man inte som utomstående kan få insikt $\mathrm{i}$ den åtalades mentala processer är däremot problemtiskt såtillvida, att detta även gäller insikten (så även Träskman). Beaktandet av vilje- och emotionella faktorer innebär enligt min uppfattning åtminstone inte ifråga om ett positivt fastställande av skulden att bevisningen blir osäkrare, men att vi får flere förhållanden som måste bevisas. Detta kan visserligen vara besvärligt för domaren - och har kanske lett till "godtycke och slentrian « (ibid. 66). Det förefaller ändå som om ett lösgörande av imputationen av skuld från den persons synvinkel vars handlingar vi värderar, skulle utgöra mindre av »formell rättvisa« än av »materiell orättvisa«.

Kravet på effektivitet kunde man på domsnivån tolka som transformerat till det $\mathrm{i}$ kriminaliseringen uttryckta »straffvärdet«, varvid det vid sidan av skulden ingår som en del av proportionalitetsprincipen. Enligt gällande finsk rätt skall detta preciseras enligt den skada och farlighet som en gärning medfört. Utgående från den här representerade synen på rättstillämpningens legitimitet borde specifieringen av detta »straffvärde« inte innebära en värdering av de sakförhållanden eller mål som kunde uppnås genom att fastställa straffvärdet på en högre eller lägre nivå i det enskilda fallet, uten »endast« fastställandet av hur stor skada på eller fara för »skyddsobjektet« som förorsakats.

Gränsdragningen blir svårare ju vagare definierade »skyddsobjekt « och »abstraktare« farekonstruktioner vi arbetar med. Vid bedömningen av en gärnings »straffvärde«, som »kan medföra skada" för »folkhushållningen«, nationens »säkerhet«, »energiförsörjning « eller »utrikesrelationer « men även t.ex. »risk för« ... »skada för miljön« (LaVo 1/89, 945-946, 978), kan det vara svårt att bedöma var gränsen går mellan att beakta den skada eller fara som förorsakats i det enskilda fallet och justifierandet och prioriterandet av värden som ingår som medel i skyddet av det »bakomliggande« värdet. Domstolen kan därför de facto komma att företa effektivitetsövervägningar i tillämpningen av rekvisiten, antingen så att man i preventivt syfte konstruerar t.ex. ett »terroristöverskott« (vilket inte torde vara okänt ens i västeuropeiska rättskulturer), eller alternativt så att andra än preventiva »effektivitetshänsyn« talar för ett lägre »straffvärde«.

Vi kan slutligen följa Frändes $(1989,1-4)$ tolkning av den tyska »Rechtstaat«-traditionen och specifiera legalitetsprincipen till fyra regler varav två, retroaktivitetsförbudet och obestämdhetsförbudet, är riktade till lagstiftaren och två, praeter legem -förbudet och analogiförbudet är riktade till domaren.

Om vi antar en faktisk grund för den ovan ( $\mathrm{i}$ avsnitt II) givna beskrivningen av rättens förvandling till »förstelnad politik« och straffrättslig »besvärjning av okända faror « kan vi föreställa oss följande problem: vad innebär praeter legem förbudet ur domarens synvinkel om lagstiftaren brutit mot obestämdhetsförbudet på ett sätt som gör det omöjligt för domaren att avgöra om en handling kan »subsumeras« under en norm eller inte? Legalitetsprincipen borde (in dubio pro reo och mi- 
tio -principerna) leda till friande i osäkra fall. Men vad är ett osäkert fall? Utgående från den förutsägbarhet som ovan antogs ligga som grund för legalitetsprincipen kan vi försöka konkretisera problemet.

Låt oss anta en så vag norm att nästan vad som helst lika väl kunde ligga »innanför « som »utanför « det förbjudna området. Tillämpningen av ett rekvisit för hypotetisk fara kunde kräva fastställandet av kausala relationer som ingen kan uttala sig varken positivt eller negativt om med beaktansvärd plausibilitet. Ett konkret fastställandet av ett skyddsobjekt som »folkhushållningen « kunde kräva sådana etiska och samhällspolitiska ställningstaganden som man brukat lämna till lagstiftaren, emedan medborgarnas uppfattnigar om hur »folkhushållningen« skall se ut skiljer sig märkbart från varandra.

Det förefaller som om den moderna straffrätten kan föra till en punkt där varken de som binder förutsägbarheten vid den individuella autonomin eller de som underbygger den med förutsägbara policy-effekter skulle vara nöjda. Senast här börjar kanske möjligheten att betrakta straffrätten som ett förnuftigt företag nå sina gränser.

Adresse: Juk assistent Kjell Sevón

Helsingfors Universitet

Regeringsgatan 11

SF-00100 Helsingfors

${ }^{1}$ Denna »lokalisering« eller »determinering« kunde betraktas dels ur det individuella »igenkännandets« synvinkel, dels i ljuset av den historiska horisonten för tolkning av mening. En analys kunde vara intressant t.ex. utgående från hermenutikens inflytande på det juridiska tänkandet eller hermeneutikens förhållande till fenomenologin samt realismens förhållande til språkets metaforiska aspekter. Till dessa frågor i ordningsföljd, se Jyrki Uusitalo 1990; Rauhala 1989, 8-11; Derrida 1985, 210-211.

2 Då den västerländska traditionen dessutom känner flere praktiska språk och former av förnuft, existerar inget entydig eller ostridigt tema för diskussionen om rättens legitimitet, varför även ett positivt svar på legitimitetsfrågan blir diskutabelt. Ett definitivt svar på frågan om legitimitet kan innebära att man väjer undan för motsättningar genom att klä en politisk ståndpunkt i förklädnaden av en epistemisk (Hänninen, ibid.).

${ }^{3}$ Utanför blir t.ex. frågan om sanktioner/reaktioner, vilket säkert mången kan uppleva som bisarrt.

${ }^{4}$ Markku Helin analyserade nyligen den »skandinaviska realismens« inflytande på nordisk och finsk jurisprudens i dette avseende. Helin konstaterar samtidigt att representanterna för skolan aldrig riktigt nådda samma nivå i sina konstruktiva förslag som i den eleganta kritiken av föreställningen om rättstillämpningen som »subsumptionslogik«. Helin 1988, särskilt 423430.

s Temat »maktens tekniker« är förmodligen bäst känt genom Michel Foucaults arbeten, särskildt hans »fängelsehistoria« (1980). Man kunde dock diskutera hur mycket Foucault - åtminstone i detta arbete - har sagt om den senaste utvecklingen inom maktens tekniker. Sakari Hänninen har t.ex. enligt min uppfattning kommit med beaktansvärda kommentarer och tillägg på de punkter där Foucaults arbete slutar, genom att bl.a. skilja mellan kontroll och övervakning, och kasta ljus över de nya formerna för »frivillig«- och självkontroll (Hänninen 1986). 
${ }^{6}$ Framställningen bygger på en grundlig analys som Kaarlo Tuori (1988a 7-56) nyligen har presenterat av hur Weber tolkad den »liberala« rättens formella rationalitet och rättens materialisering i »välfärdsstaten«.

${ }^{7}$ Artikeln utgör ett försök att besvara frågan om straffrättens koherens genom att undersöka systemets justifikationer, vilket motsvarar den grunduppfattning av koherensproblemet i konstruktionen av ett rättssystem som föreslagits idenna artikel (ovan, avdelning I). Saken kan illustreras med en jämförelse av artikelns svenska rubrik med rubriken på en bearbetad och utvidgad version på engelska: "The Coherence of the Penal System « (Jareborg 1988a, 105-121). ${ }^{8}$ Detta syns bl.a. i två enligt min åsikt viktiga doktorsavhandlingar i straffrätt: Lappi-Seppäläs om straffmätning (1987) och Frändes om legalitetspricipen (1989).

${ }_{9}^{9}$ Alexy 1989 utgör t.ex. ett försök att ur olika synvinklar bevisa existensen av ett begreppsligt band mellan rätt och moral.

${ }^{10}$ Man måste uppenbarligen även inom straffrätten skilja mella olika typer av frågor: beslutet att åtala skiljer sig i detta avseende från t.ex. avgörandet av skuld- och ansvarsfrågor, vilka i sin tur skiljer sig från straffmätningen. När man besluter om väckande av åtal kan man t.ex. beakta intresset av utredning eller offentlighet jämnsides med - eller mot - »intresset « av en fällande dom eller bestraffning. Straffmätning förefaller i sin tur svårt att föreställa sig utan någon form av avvägning eller balanserande av värden och principer.

11 Samtliga argument återfinns i Tapio Lappi-Seppäläs avhandling, 1987, 166-195.

${ }^{12}$ För denna utgångspunkt se Frände 1989, 230-232. Det kan dock konstateras att både LappiSeppälä och Frände arbetar med en av Dworkin och - framförallt - Alexy inspirerad metod som innefattar avvägning av principer, värden och målsättningar. Båda författarna diskuterar såväl empiriska och pragmatiska argument som det som jag har betecknat som det normativa (autonomi)kriteriet. Mina hänvisningar till författarna kan därför anses selektivt valda för mina egna avsikter.

${ }^{13}$ Denna beskrivning lämnar de inskränkningar och den ambivalens ifråga om participationstesen och dess faktiska realisation obehandlade, vilka kan utläsas ur Kants texter, t.ex. 1986 $142,145,54-56$.

14 Vare sig Binding eller von Liszt, våra exempel på en »klassisk « straffrättsdebatt, visade särdeles mycket förståels för frågan om demokratisk participation som grund för rättens legitimitet: Binding tycktes ersätta den med en uppsättning normer som var inbyggda i den nationella kulturen eller hade sitt ursprung i en för alla bindande praktiskt-moralisk rationalitet; von Liszt tycktes ersätta demokratiskt deltagand med »social engineering « och tro på de positivistiska samhällsvetenskapernas förmåga att presentera allmängiltiga rationella lösningar (Binding 1907, von Liszt 1980, se även Sevón 1989, 414-418).

${ }^{15}$ Habermas diskussion av förhållandet mellan den procedurala diskursetiken, politik och rättens legitimitet i ett modernt, posttraditionellt samhälle (t.ex. 1988a, 345-366; 1987; 1989) har gett upphov till olika tolkningar av »diskursens« förhållande till rättstillämpningen: Alexy ser rättstillämpningen som ett specialfall av den praktiska diskursen (1983, 261-272), vilken tes även Habermas senare anslutit sig till (1988a, 62-63). Aarnio ser acceptabiliteten inom ett auditorium av »rationella personer« som en av förutsättningarna för ett rättsligt avgörandes validitet (t.ex. 1989).

${ }^{16}$ Däremot kunde man diskutera hur s.k. standarder för beteendet, som i och med samhällets differentiering tycks få allt större betydelse även inom straffrätten, förhåller sig till olika konceptioner av rättens »reflexivering«. Den diskussionen kunde särskilt ta fasta på en »demokratisering « av sakkunnigutlåtanden.

17 Jag har tidigare försökt behandla frågan i samband med strafflagsprojektets första »delpaket« $(5 / 84)$ i anslutning till kriminaliseringen av »bostadsockupation«. Därvid försökte jag för övrigt bl.a. utnyttja Alexys kollisionslag tillämpad på nivån för kriminaliseringar, d.v.s. lagstiftning (Sevón 1988). 
Litteratur:

Aarnio, Aulis: Philosophical Perspectives in Jurisprudence. Acta Philosophica Fennica. Vol 36. Helsinki 1983.

Aarnio, Aulis: Laintulkinnan teoria. Porvoo-Helsinki-Juva 1989.

Alexy, Robert: Theorie der juristischen Argumentation. Frankfurt am Main 1983.

Alexy, Robert: Theorie der Grundrechte. Frankfurt am Main 1986.

Alexy, Robert \& Peczenik, Alexander: The Concept of Coherence and its Significance for Discursive Rationality. Ratio Juris Vol. 3 1990, 130-148.

Cotterell, Roger: The Politics of Jurisprudence. A Critical Introduction to Legal Philosophy. London - Edinburgh 1989.

Beck, Ulrich: Risikogesellschaft. Auf dem Weg in eine andere Moderne. Frankfurt am Main 1986.

Binding, Karl: Grundriss des Deutschen Strafrechts. Allgemeiner Teil. Leipzig 1907.

Björne, Lars: Oikeusjärjestelmän kehityksestä. Helsinki 1986.

Blom, Raimo: Luottamus oikeuslaitokseen. Tampere 1976.

Bondeson, Ulla: Rättsmedvetandet rörande brottens straffvärde och domarens straffmätning. Brå 1980: 2 .

Christie, Nils: Konflikt som eiendom. TfR 1977, 113-132.

Derrida, Jacques: Die Schrift und die Differenz. Frankfurt am Main 1985.

Dworkin, Ronald: Taking Rights Seriously. London 1981.

Dworkin, Ronald: Laws Empire. London 1986.

Eriksson, Lars. D: Rätten och moralen. Retfærd 48 (1/1990), 4-13.

Eser, Albin Kaiser, Günther \& Madlener, Kurt: Neue Wege der Wiedergutmachung im Strafrecht. Freiburg i. Br. 1990.

Frände, Dan: Den straffrättsliga legalitetsprincipen. Ekenäs 1989.

Frände, Klaus: Farebegreppet och strafflagsreformen. JFT 1990 (häfte 2 \& 3), 95-115.

Günther, Klaus: A normative Conception of Coherence for a Discursive Theory of Legal Justification. Ratio Juris. Vol. 2 1989, 155-167.

Habermas, Jürgen: Strukturwandel der Öffentlichkeit. Neuwied 1962.

Habermas, Jürgen: Legitimation Crisis. London 1976.

Habermas, Jürgen: Wie ist Legitimität durch Legalität möglich? Kritische Justiz 1/1987, 1-16.

Habermas, Jürgen: Theorie des Kommunikativen Handelns. Band I, Handlungsrationalität und gesellschaftliche Rationalisierung, Frankfurt am Main 1988. (Habermas 1988a).

Habermas, Jürgen: Theorie des Kommunikativen Handelns. Band II, Kritik der funktionalistischen Vernunft Frankfurt am Main 1988 (Habermas 1988b).

Habermas, Jürgen: Towards a Communication-Concept of Rational collective Will-Formation. Ratio Juris. Vol. 2 1989, 144-154.

Hassemer, Winfried: Symbolinen rikosoikeus ja oikeushyvien suojelu. Oikeus 1989: 5, 388400.

Helin, Markku: Lainoppi ja metasysiikka. Vammala 1988.

Hellner, Jan: Rättsteori. En introduktion. Stockholm 1988.

Herzog, Felix: Gesellschaftliche Unsicherheit und strafrechtliche Daseinsvorsorge. Frankfurt am Main 1989 (Habilitationsarbete, ännu inte kommersiellt tillgängligt).

Honkasalo, Brynolf: Suomen rikosoikeus. Yleiset opit. Toinen osa. Helsinki 1967. 
Hänninen, Sakari: Legitimiteetistä. I Hirvonen - Tuori (red.): Oikeus, kieli ja kritiikki. Helsinki 1990, 1-21.

Hänninen, Sakari: Valtiosta valtaan. Helsinki 1986.

Jareborg, Nils: Om straffets syfte och berättigande. TfK 1/1985, 1-19.

Jareborg, Nils: Essays on Criminal Law. Uppsala 1988 (Jareborg 1988a).

Jareborg, Nils: Rättvisa och repressionsnivå. I Tuori, Kaarlo (ed.): Rättsdogmatikens alternativ. Tammerfors 1988 (Jareborg 1988b).

Kant, Immanuel: Metaphysische Anfangsgründe der Rechtstheorie. Hamburg 1986.

Kelsen, Hans: The Function of a Constitution. I Tur - Twining (red.): Essays on Kelsen. Oxford 1986, 11-119.

Kennedy, David: The Turn to Interpretation. Southern California Law Review (Vol. 57:237) 1985, 251-275.

Kommittebetänkande 1976: 72. Straffrättskommittens principbetänkande.

Lagerspetz, Eerik: A Conventionalist Theory of Institutions. Acta Philosophica Fennica, Vol. 44. Helsinki 1989.

Lappi-Seppälä, Tapio: Rangaistuksen määräämisestä I. Vammala 1987.

Lavo 5/84: Rikoslain kokonaisuudistus I. Rikoslakiprojektin ehdotus. Oikeusministeriön lainvalmisteluosaston julkaisu 5/1984.

Lavo 1/89: Rikoslain kokonaisuudistus II. Rikoslakiprojektin ehdotus. Oikeusministeriön lainvalmisteluosaston julkaisu 1/1989.

von Liszt, Franz: Von der Rache zur Zweckstrafe (Herausgeber Heribert Ostendorf). Frankfurt am Main 1980.

Maus, Ingeborg: The Differentiation between Law and Morality as a Limitation of Law. I Aarnio - Tuori, (red.): Law, Morality and Discursive Rationality. Helsinki 1989, 141-164.

Maus, Ingeborg: Rechtstheorie und politische Theorie im Industriekapitalismus. München 1986.

Nuutila, Ari-Matti: On the Principle of Guilt in Finnish Criminal Law - Intentionality, Knowledge and Motivational Factors as Preconditions for Criminal Liability. I Lahti, Raimo - Nuotio, Kimmo (red.): Towards a Total Reform of Finnish Criminal Law. Publications of the Department of Criminal Law and Judicial Procedure B:2, University of Helsinki 1990, 101-157.

Pöyhönen, Juha: Sopimusoikeuden järjestelmä ja sopimusten sovittelu. Vammala 1988.

Rauhala, Lauri: Hermeneuttinen näkökulma mertityksen ongelmaan. Tiedepolitiikka 3/89, 314.

Rousseau, Jean-Jacques: Ausgewählte Texte. München 1988.

Sevón, Kjell: Kriminaalipolitiikan käsite ja Honkasalo. I Lahti, Raimo (red.): Rikosoikeudellisia kirjoitelmia VI. Vammala 1989, 384-421.

Sevón, Kjell: Näkökulma asunnonvaltauksen kriminalisointiin. Oikeus 1988:3, 305-312.

Straffrättskommittens betänkande. Band I, 1976:72.

Träskman, P. O.: Kan gärningspersonens uppsåt bevisas med hållpunkter i sinnevärlden? I Jareborg - Träskman (red.) Skuld och ansvar. Uppsala 1985, 56-75.

Tuori, Kaarlo: The general Doctrines of Public Law. Scandinavian Studies in Law 1987, $177-$ 191. 
Tuori, Kaarlo: Oikeuden rationaalisuus. Max Weber ja Jürgen Habermas oikeuskehityksen tulkitsijoina. Helsinki 1988 (Tuori 1988a).

Tuori, Kaarlo: Alternativ eller kritik, snäv eller utvidgad doktrin. I Tuori, Kaarlo (red.): Rättsdogmatikens alternativ. Tammerfors 1988, 159-210 (Tuori 1988b).

Tuori, Kaarlo: Discursive Ethics and the Legitimacy of Law. Ratio Juris. Vol. 2 1989, 125-143. Tuori, Kaarlo: Oikeus, valta ja demokratia. Helsinki 1990.

Uusitalo, Jyrki: Gadamer, Dworkin ja oikeuden hermeutiikka. I Hirvonen - Tuori (red.): Oikeus, kieli ja kritiikki. Helsinki 1990, 129-139.

Uusitalo, Liisa: Efficiency, Effectiveness and Legitimation: Criteria for the Evaluation of Norms. Ratio Juris, volume 2 1989, 194-201.

Weber, Max: Wirtschaft und Gesellschaft. Studienaufgabe. Tübingen 1980.

von Wright, G. H.: Logiikka, filosofia ja kieli. Helsinki 1968.

von Wright, G. H.: Introduction. Ratio Juris, volume 2 1989, 121-123. 